AperTO - Archivio Istituzionale Open Access dell'Università di Torino

\title{
Laying the foundations for a formal theory of drama
}

\section{This is the author's manuscript}

Original Citation:

\section{Availability:}

This version is available http://hdl.handle.net/2318/29011

since

Publisher:

Springer

Published version:

DOI:10.1007/11558590_29

Terms of use:

Open Access

Anyone can freely access the full text of works made available as "Open Access". Works made available under a Creative Commons license can be used according to the terms and conditions of said license. Use of all other works requires consent of the right holder (author or publisher) if not exempted from copyright protection by the applicable law. 
1 Dipartimento di Informatica and CIRMA, Cso Svizzera, 185 Torino, Italy

2 DAMS and CIRMA, Via S. Ottavio 20, Torino Italy

\begin{abstract}
The goal of this research is to lay the foundations for a formal the of drama, that abstracts from the procedural and interactive aspects involvec the generation of dramatic content. The theory characterizes dramatic qualities reconciling the structural accounts provided by traditional drama analysis with agent-based perspective on characters.
\end{abstract}

\title{
1 Motivations and Formalization
}

In the design of AI systems for communication and entertainment, much att been devoted to the dramatic qualities exhibited by interactive applications. T plications span from artificial characters for entertainment and instruction, to systems for storytelling and drama [1|2|3]. The aim of this paper is to lay th tions of a formal theory that systematizes the basic aspects of drama in a explicit model, with an immediate integration with agent-based theories. T called Drammar, abstracts from the interactive and procedural aspects of dra ation, and is intended as the starting point for specifying, implementing and practical storytelling systems in a principled way.

The notions of direction, character and plot, pervasive throughout the lit drama analysis since Aristotle, are the three main components of the drame incorporated in Drammar. The goal of a drama is to make audience percei intuitively called a "story" by displaying the actions of some characters i actions are organized in a plot; the plot moves toward a direction. Concerning ture of drama, it has been a well known convention to segment the list of a form a drama into a number of units or sections [6]. Such units, despite term disparities, are of the same nature, so that some authors define drama as a re "fractal" structure [7].

Drammar is structured in two levels: the actional level models the intentio iour of the characters in a plot as intelligent, goal-directed agents. The direct accounts for dramatic meaning, abstracting from the intentionality of the through the use of attributes that model the effect of plot incidents onto the $c$ rational and emotional state. The drama direction is a change function that $t$ the rational and emotional state of a character into a different state [4]. Such defined through values assigned to a number of attributes of the characters ( tis personae), defined as a set of attributes. The set of attributes defining a combines a rational, BDI perspective with an emotional component.

S. Bandini and S. Manzoni (Eds.): AI*IA 2005, LNAI 3673, pp. 286 2892005.

(C) Springer-Verlag Berlin Heidelberg 2005 
The Direction is a function $D$ that specifies the value changes of the c attributes after the execution of the plot. So, the domain of the direction fur State (where a State is a set of Polarities of attributes), and the co-domain State. So, let a State be $\bigcup_{i} C H A R_{i}$.POLARITY:

$$
\mathcal{D}: \text { State }_{i} \rightarrow \text { State }_{f}
$$

The relationship between the value changes of the rational/emotional st characters and the actual actions and events listed in a drama is stated at th level through the notion of drama goal. The drama goal is the world state th the Direction, and it is operatively specified as the achievement or the negat goal of a certain character, namely the drama protagonist.

The Plot is the component that carries out the polarity inversions descril Direction function. The Plot is a sequence of elementary units called called $b$ actional units formed by a action-reaction pair [6]. Notice that some Bea change any attribute value, but every change does occur in some Beat.

The three components described above form a Drama-unit, that represent all the basic aspects of drama. Formally, a Drama-unit is a triple:

- Dramatis_personae is a finite set of Dramatis_persona;

- Direction is a function $\mathcal{D}$ defined as above;

- Plot is a list of Beats $\left\langle B_{1}, B_{2}, \ldots, B_{m}\right\rangle$,

and the condition holds that at least one attribute inverts its polarity.

In Drammar, drama-units are subdivided into smaller drama-units, resultir of drama-units. The leaves of this tree are directly connected to beats, and its properly called drama, the highest-level unit that subsumes the entire sequenc and is not subsumed by other drama-units. The units of the drama and their are combined in a drama-specific progression related with the emotional enga the audience via the protagonist's fate. Dramatic actions in the plot trace a cu to the fulfilment of the direction. Each drama-unit, with its goal, has both position and a dramatic value within the plot. This value is given by the value changes that occur within the unit, either in a beat directly included by in a beat included in one of its sub-units.

\section{An Example}

We apply the formal system Drammar to the definition of a linear drama, known Hitchcock's North by Northwest [8] (see the table in Figure1). North west is about a middle-aged advertising executive Roger Thornhill who is mi the (non-existent) government agent George Kaplan by a gang of spies lead b damm. He gets involved in a series of misadventures and is pursued across 


\begin{tabular}{|c|c|c|c|c|c|}
\hline 2 & $\begin{array}{l}\text { R. gets aware of } \\
\text { mismatch and tries get } \\
\text { out of trouble }\end{array}$ & Involved (Roger) True & Individualism & - & BELIEF.norms \\
\hline 2.1 & R. meets Vandamm & Agreement (Roger,Vandamm) False & Disappointment & + & $\begin{array}{l}\text { EMOTION.prospect- } \\
\text { based }\end{array}$ \\
\hline 2.1.1 & $\begin{array}{l}\text { Vandamm addresses } \\
\text { R. as Kaplan }\end{array}$ & Mentioned (Vandamm,Kaplan) True & Distress & + & $\begin{array}{l}\text { EMOTION.well- } \\
\text { being }\end{array}$ \\
\hline 2.1.2 & $\begin{array}{l}\text { Vandamm threatens } \\
\text { R. of death }\end{array}$ & Threatened (Vandamm.Roger) True & Anger & + & $\begin{array}{l}\text { EMOTION.well- } \\
\text { being/attribution }\end{array}$ \\
\hline 2.1.3 & $\begin{array}{l}\text { Vandamm's gang tries } \\
\text { to kill R.; R. escapes }\end{array}$ & Killed (gang, Roger) False & Relief & + & $\begin{array}{l}\text { EMOTION.prospect- } \\
\text { based }\end{array}$ \\
\hline 2.2 & $\begin{array}{l}\text { Nobody believes R.; } \\
\text { R. accused of } \\
\text { shooting Townsend }\end{array}$ & Outcast (Roger) True & Isolation & + & BELIEF.world-state \\
\hline 2.2.1 & $\begin{array}{l}\text { R.'s report not } \\
\text { believed by anybody }\end{array}$ & Discredited (Roger) True & Anger & + & $\begin{array}{l}\text { EMOTION.well- } \\
\text { being/attribution }\end{array}$ \\
\hline 2.2 .2 & R. leaves his mother & Left (Roger.Mother) True & Submission & - & BELIEF.social \\
\hline 2.2 .3 & $\begin{array}{l}\text { R. is believed to have } \\
\text { killed Townsend }\end{array}$ & $\begin{array}{l}\text { Falsely_accused } \\
\text { (Roger.assassination) True }\end{array}$ & Disappointment & + & $\begin{array}{l}\text { EMOTION.prospect- } \\
\text { based }\end{array}$ \\
\hline 2.3 & $\begin{array}{l}\text { R. escapes police, } \\
\text { meets Eve, seduction, } \\
\text { fake appointment }\end{array}$ & Seduced (Eve.Roger) True & Love & + & EMOTION.attraction \\
\hline 2.3.1 & R. runs away by train & Caught (Roger.Train) True & Relief & + & $\begin{array}{l}\text { EMOTION.prospect- } \\
\text { based }\end{array}$ \\
\hline 2.3.2 & $\begin{array}{l}\text { E. hides R. from } \\
\text { police in the cabin }\end{array}$ & Hidden (Roger) True & Gratitude & + & $\begin{array}{l}\text { EMOTION.well- } \\
\text { being-attribution }\end{array}$ \\
\hline 2.3.3 & $\begin{array}{l}\text { R. and E. sleep } \\
\text { together }\end{array}$ & Had_sex (Roger.Eve) True & Satisfaction & + & $\begin{array}{l}\text { EMOTION.prospect- } \\
\text { based }\end{array}$ \\
\hline 2.3.4 & $\begin{array}{l}\text { E. fixes the fake } \\
\text { appointment with } \\
\text { Kaplan }\end{array}$ & Deceived (Eve,Roger)True & Hope & + & $\begin{array}{l}\text { EMOTION.prospect- } \\
\text { based }\end{array}$ \\
\hline 2.3.5 & $\begin{array}{l}\text { Airplane tries to kill } \\
\text { R. }\end{array}$ & Meeting (Roger,Kaplan) False & Disappointment & + & $\begin{array}{l}\text { EMOTION.prospect- } \\
\text { based }\end{array}$ \\
\hline 2.4 & $\begin{array}{l}\text { R. calls E.'s bluff and } \\
\text { Professor explains }\end{array}$ & Explain (Professor,Roger) True & Anger & + & $\begin{array}{l}\text { EMOTION.well- } \\
\text { being-attribution }\end{array}$ \\
\hline 2.4 .1 & R. discloses E. & Deceive (Eve,Roger) False & Reproach & 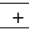 & EMOTION.attributiol \\
\hline 2.4 .2 & $\begin{array}{l}\text { R. finds about } \\
\text { Vandamm and } \mathrm{E} \text {. }\end{array}$ & Unmasked (Roger.Vandamm) True & Anger & + & $\begin{array}{l}\text { EMOTION.well- } \\
\text { being-attribution }\end{array}$ \\
\hline 2.4.3 & $\begin{array}{l}\text { R. arrested and meets } \\
\text { Prof. }\end{array}$ & Meeting (Professor,Roger) True & Truth & + & BELIEF.world-state \\
\hline 2.4 .4 & E.'s identity revealed & Revealed (Eve's identity,Roger) True & Pity & + & $\begin{array}{l}\text { EMOTION.fortune- } \\
\text { of-others }\end{array}$ \\
\hline 3 & R. takes revenge & Married (Roger,Eve) True & Family & + & BELIEF.norms \\
\hline 3.1 & $\begin{array}{l}\text { E. pretends shooting } \\
\text { R. at M. Rushmore }\end{array}$ & Collaboration (Roger,Eve) True & Relationship & + & BELIEF.social \\
\hline 3.1.1 & E. fake-shoots R. & Deceived (Roger,Vandamm) True & Satisfaction & + & $\begin{array}{l}\text { EMOTION.prospect- } \\
\text { based }\end{array}$ \\
\hline 3.1.2 & $\begin{array}{l}\text { E. to leave with } \\
\text { Vandamm }\end{array}$ & Coupled (Roger,Eve) True & Love & + & EMOTION.attraction \\
\hline 3.2 & $\begin{array}{l}\text { Chase and fight at M. } \\
\text { Rushmore }\end{array}$ & Saved (Roger.Eve) True & Gratification & + & $\begin{array}{l}\text { EMOTION.well- } \\
\text { being/attribution }\end{array}$ \\
\hline 3.2.1 & $\begin{array}{l}\text { R. escapes from } \\
\text { hospital }\end{array}$ & Rebellion (Roger,Professor) True & Independence & + & BELIEF.normative \\
\hline 3.2.2 & $\begin{array}{l}\text { Leonard discloses } \\
\text { Eve's secret }\end{array}$ & $\begin{array}{l}\text { Informs (Leonard,Vandamm, Eve's } \\
\text { trick) True }\end{array}$ & Fear & + & $\begin{array}{l}\text { EMOTION.prospect- } \\
\text { based }\end{array}$ \\
\hline 3.2.3 & $\begin{array}{l}\text { R. kills Leonard on } \\
\text { M. Rushmore }\end{array}$ & Killed (Roger,Leonard) True & Relief & + & $\begin{array}{l}\text { EMOTION.prospect- } \\
\text { based }\end{array}$ \\
\hline
\end{tabular}

Fig. 1. Analysis of North by Northwest

by both the spies and the government whilst being helped by a beautiful $b$ Kendall. Eventually, he will discover that Eve is an undercover CIA agent an they will defeat the evil gang, on a thrilling sequence on the Mount Rushmor

The first column, ID, reports the hierarchical structure of Drama-units in Northwest (the table rows); the levels of the hierarchy correspond to acts, sequ scenes in the standard filmic terminology. The second column, Description 
have been affected, so as to make him more inclined to help the others (the "Involved (Roger)" becomes true). This goal is in turn accomplished trough t goals of the sub-units of that unit: Roger's individualism is affected by the ne himself out the troubles he got into (Sequences 2.1 and 2.2), by Eve's sedu and by the awareness of a conflict between the CIA and Vandamm (2.4).

The last three columns, Attribute, Value and Attribute-type, describe the d each Drama-unit. For example, in Act I, Roger falls into an emotional state of a consequence of being kidnapped by Vandamm's gang, setting the "distress to +; in the second act, Roger's "individualism" is set + . The subtype of eac is expressed by the dot notation: for example, "BELIEF.norms" referred to alism" means that this attribute belongs to the normative component of the $c$ beliefs, which are part of the rational component of the character. For em notation refers to the emotional classes described in OCC model [5].

\section{Conclusions and Future Work}

The definition of drama proposed in this paper is a first step toward a comp formal system for analyzing and generating drama. The current theory leave research the task of identifying the instruments by which the formal mod incorporated into practical systems.

The theory describes drama as an off-line object, and does not specifical the interactive generation of drama. The extension of the provisional model $t$ linear case, where the list of units in the plot is not pre-determined, represen line of research in the development of a comprehensive theory.

\section{References}

1. Bryan Loyall, A., Bates, J.: Personality-rich belivable agents that use language Johnson, W., ed.: Proc. of the First Int. Conference on Autonomous Agents. (1997

2. Staller, A., Petta, P.: Towards a tractable appraisal-based architecture. In Can Numaoka, C., Petta, P., eds.: Workshop: Grounding Emotions in Adaptive System

3. Cavazza, M., Charles, F., Mead, S.: Interacting with virtual characters in intera telling. In: Proc. of AAMAS02 (2002)

4. Egri, L.: The Art of Dramatic Writing. Simon and Schuster, New York (1960 (194

5. A. Ortony, G.C., Collins, A.: Cognitive Stucture of Emotions. Cambrige Univ. Pr

6. McKee, R.: Story. Harper Collins, New York (1997)

7. Lavandier, Y.: La dramaturgie. Le clown et l'enfant, Cergy (1994)

8. E.Lehman: North by Northwest. Directed by A. Hitchcock. Photographed by R. F C. Grant, E. M. Saint, J. Mason. Metro Goldwyn Mayer (1959) 